\title{
PROTOTIPE SISTEM PENGUKUR KETINGGIAN PERMUKAAN SAMPAH PADA TEMPAT PEMBUANGAN SEMENTARA MENGGUNAKAN ARDUINO DAN WEB GIS
}

\author{
Didi Ariadi'), Tashid ${ }^{2)}$ \\ 1,2,Teknik Informatika, STMIK Amik Riau, Jl. Purwodadi Km 10,5 Pekanbaru \\ email: didiariadi77@gmail.com, tashid@stmik-amik-riau.ac.id
}

\begin{abstract}
Trash is waste that is not used can be in the form of solid, liquid, or gas. Trash makes the environment uncomfortable because it causes the stench. Garbage problem becomes an obstacle in every city in Indonesia. Pekanbaru city is a city has a problem of waste management, because it has a dense population. Garbage dumps are scattered at some point like in markets, malls, and residential neighborhoods throughout the city. To handle garbage cleaners routinely transport garbage from landfills temporarily once a day. The problem is that the number of garbage dumps makes it difficult for janitors to control and control the waste, which can result in waste not being transported on the same day. The number of garbage dumps while making the officers do not know the landfill is full. This is what underlies the authors make prototype of garbage height measurement system in temporary dumping place using arduino integrated with web gis. The purpose of making the system to provide alarm warnings to the janitor cleaner where the temporary garbage disposal is full. Also to control the maximum capacity of realtime landfills through online maps. As the system progresses it will help the janitor know the location of the garbage has accumulated. The officer will prioritize the already completed disposal site for transport to final disposal.
\end{abstract}

Keywords: Trash, Arduino, Web GIS, prototype

\begin{abstract}
Abstrak
Sampah adalah limbah yang tidak digunakan lagi bisa dalam bentuk padat, cair, atau gas. Sampah membuat lingkungan tidak nyaman karena menyebabkan bau busuk. Masalah sampah menjadi kendala pada setiap kota di indonesia. Kota pekanbaru merupakan kota memiliki masalah pengelolaan sampah, karena memiliki penduduk yang padat. Tempat pembuangan sampah tersebar di beberapa titik seperti di pasar, mall, dan pemukiman penduduk di seluruh kota. Untuk menangani sampah petugas kebersihan secara rutin mengangkut sampah dari tempat pembuangan sampah sementara sekali dalam sehari. Masalah yang timbul adalah banyaknya tempat pembuangan sampah menyulitkan petugas kebersihan untuk mengendalikan dan mengontrol sampah, yang dapat mengakibatkan sampah tidak diangkut pada hari yang sama. Banyaknya tempat pembuangan sampah sementara membuat petugas tidak mengetahui tempat pembuangan sampah yang sudah penuh. Hal inilah yang mendasari penulis membuat prototipe sistem pengukuran ketinggian sampah di tempat pembuangan sementara menggunakan arduino terintegrasi dengan web gis. Tujuan pembuatan sistem untuk memberikan peringatan alarm pada petugas kebersihan tempat pembuangan sampah sementara sudah penuh. Juga untuk mengontrol kapasitas maksimum realtime tempat pembuangan sampah melalui peta secara online. Dengan berjalannya sistem ini akan membantu petugas kebersihan mengetahui lokasi sampah sudah menumpuk. Petugas akan memprioritaskan tempat pembuangan yang sudah penuh untuk diangkut ke pembuangan akhir.
\end{abstract}

Kata Kunci: Sampah, Arduino, Web GIS, prototipe

\section{PENDAhUluAN}

Sampah merupakan sisa material yang sudah tidak digunakan lagi setelah suatu proses. Sampah dapat dihasilkan oleh semua makhluk hidup baik dari hewan, manusia, maupun tumbuhan. Undang-Undang Pengelolaan Sampah Nomor 18 tahun 2008 menyatakan sampah adalah material sisa, yang diproduksi ke alam baik dalam bentuk padatan, cair, ataupun gas. Sampah tidak hanya merupakan sumber polutan bagi manusia dan lingkungan sekitarnya, tetapi sampah juga menjadi sarang bibit penyakit, hal ini membuat lingkungan menjadi tidak nyaman karena bau tidak sedap yang ditimbulkan dan belum lagi ketika timbunan sampah yang masuk ke dalam saluran drainase yang mengakibatkan saluran 
tersumbat dan ketika hujan akan timbulnya bahaya banjir.

Dinas Pertamanan (DKP) Kota Pekanbaru, Riau, Indonesia mencatat volume sampah pemukiman per harinya mencakup seluruh kecamatan yang ada di Kota Pekanbaru mencapai 1502.901 liter/hari dengan banyak penduduk sebanyak 1021.8 jiwa, dengan rata-rata menghasilakn sampah per harinya untuk permukiman sederhana 540.562 liter/hari, sedangkan permukiman menengah menghasilkan sampah 634.917 liter/hari dan untuk permukiman mewah menghasilkan sampah sebanyak 327.422 liter/hari (dkp pekanbaru, 2015).

Jumlah penduduk yang semakin meningkat dapat mempengaruhi produksi material sisa. Semakin banyak jumlah penduduk, maka sampah yang dihasilkan juga akan semakin besar tapi kuantitas pengangkutan sampah tidak ditambah. Sistem yang berjalan pada saat ini adalah petugas kebersihan hanya akan mengangkut sampah di TPS sekali dalam sehari yaitu pada sore hari. Hal lain yang pernah ditemui adalah petugas sampah terkadang tidak melakukan pengambilan jika sampah pada TPS Sementara masih sedikit.

Berdasarkan penjelasan masalah di atas maka penulis merasa perlu membuat alat yang dapat memantau ketinggian atau kapasitas sampah di TPS sementara yang ada di Kota Pekanbaru, dengan melakukan pengembangan dari penelitian sebelumnya. Pada penelitian sebelumnya yang terdapat dalam tinjauan pustaka membahas tentang perancangan sistem pendeteksi kapasitas tempat sampah secara otomatis pada kompleks perumahan (Dedi Setiawan \& dkk, 2013). Sistem yang telah dibuat perlu dikembangkan karena masih terdapat kekurangan, yaitu komunikasi yang masih menggunakan pemancar FM (Radio Frekuensi) yang dapat terganggu apabila keadaan cuaca buruk mengakibatkan data tidak sampai kepada penerima dan jarak pengiriman data juga lebih pendek, dan belum berbasis web gis.

Adapun kelebihan yang akan dibuat adalah alat yang dirancang menggunakan koneksi internet yang apabila dalam keadaan cuaca buruk maka koneksi tetap stabil dan memiliki jarak pengiriman data yang lebih panjang daripada pemancar FM. Penulis juga menambahkan sistem informasi geografis untuk memetakan sebaran TPS yang ada di Kota Pekanbaru sehingga memudahkan petugas dalam memantau kapasitas TPS yang tersebar.

\section{LANDASAN TEORI}

Beberapa teori dasar yang terkait dalam penelitian ini, masing-masing teori akan dijelaskan di bawah ini antara lain adalah sistem, mikrokontroller arduino, dan gis.

\section{Sistem}

Sistem adalah sekumpulan elemen yang saling terkait atau terpadu yang dimaksudkan untuk mencapai suatu tujuan (Kadir, 2003). Ada beberapa komponen yang dapat membentuk sebuah system yakni tujuan, masukkan, masukkan dan keluaran.

Sistem informasi adalah suatu sistem di dalam suatu organisasi yang mempertemukan kebutuhan pengolahan transaksi harian yang mendukung fungsi operasi yang bersifat manajerial dengan kegiatan strategi dari suatu organisasi untuk dapat menyediakan kepada pihak luar tertentu dengan laporan-laporan yang diperlukan (Sutabri, 2012). Untuk mendukung sistem informasi ini dibutuhkan sistem basis data dan bahasa pemrograman, pada penelitian ini digunakan php dan mysql.

Menurut Syaifudin Ramadhani Jurnal Teknika Vol. 5 No.2 (2013) PHP adalah bahasa pemrograman script yang paling banyak dipakai saat ini. PHP banyak dipakai untuk memrogram situs web dinamis, walaupun tidak tertutup kemungkinan digunakan untuk pemakaian lain.

MySQL adalah sebuah perangkat lunak sistem manajemen basis data SQL (bahasa Inggris: database management system) atau DBMS yang multithread, multiuser, dengan sekitar 6 juta instalasi di seluruh dunia. MySQL adalah Relational Database Management System (RDBMS) yang didistribusikan secara gratis dibawah lisensi GPL (General Public License). Dimana setiap orang bebas untuk menggunakan MySQL, namun tidak boleh dijadikan produk turuna yang bersifat komersial

\section{Geografis Information System (GIS)}

SIG merupakan sebagai satu kesatuan formal yang terdiri dari berbagai sumber daya fisik dan logika yang berkenaan dengan objekobjek penting yang terdapat dipermukaan bumi (Prahasta, 2009). Jadi, SIG juga merupakan sejenis perangkat lunak, perangkat keras (manusia, prosedur, basis data, dan 
fasilitas jaringan komunikasi) yang dapat digunakan untuk memfasilitasi proses pemasukan, penyimpanan, manipulasi, menampilkan, dan keluaran data/informasi geografis berikut atribut-atribut terkait

\section{Mikrokontroller}

Menurut Ari Beni Santoso Jurnal FEMA, Volume 1, Nomor 1 (2013) Pengertian Mikrokontroler adalah sistem mikroprosesor lengkap yang terkandung di dalam sebuah chip. Mikrokontroler berbeda dari mikroprosesor serba guna yang digunakan dalam sebuah PC, karena sebuah mikrokontroler umumnya telah berisi komponen pendukung sistem minimal mikroprosesor, yakni memori dan pemrograman Input-Output.

\section{Arduino Uno Atmega328}

Menurut Dedi Setiawan (2014) Arduino Uno adalah board yang menggunakan mikrokontroler ATmega328. Arduino Uno berbasis mikroprosesor (Berupa Atmel AVR) dan dilengkapi dengan oscillator $20 \mathrm{MHz}$ (yang memungkinkan operasi berbasis waktu dilaksanakan dengan cepat) dan regulator (pembangkit tegangan) 5 Volt (gambar 2.1).

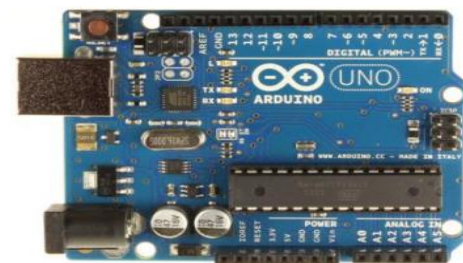

Gambar 1. Arduino Uno Atmega328

(Sumber : http://www.farnell.com/)

\section{Sensor Ultrasonik HC-SR04}

Menurut Sinatya Feranti Anindya (2015) Modul HC-SR04 (Gambar 2.2) merupakan modul sensor ultrasonik yang memiliki fungsi utama sebagai pengukur jarak. Modul ini terdiri atas sepasang transduser dengan empat pin, yaitu pin suplai tegangan (Vcc), pin trigger, pin echo, dan pin ground. Modul akan memulai pengukuran saat diberi sinyal pulsa trigger sepanjang $10 \mu \mathrm{s}$, di mana transmitter akan mengirimkan gelombang ultrasonik yang akan diterima kembali oleh receiver saat gelombang tersebut mengenai obyek dan memantul (gambar 2.2).

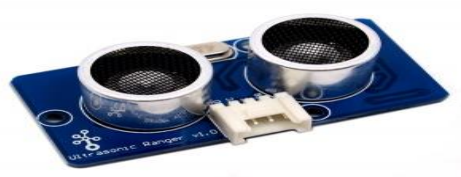

Gambar 2. Sensor Ultrasonik HC-SR04 (Sumber: http://www.seeedstudio.com)

\section{METODE PENELITIAN}

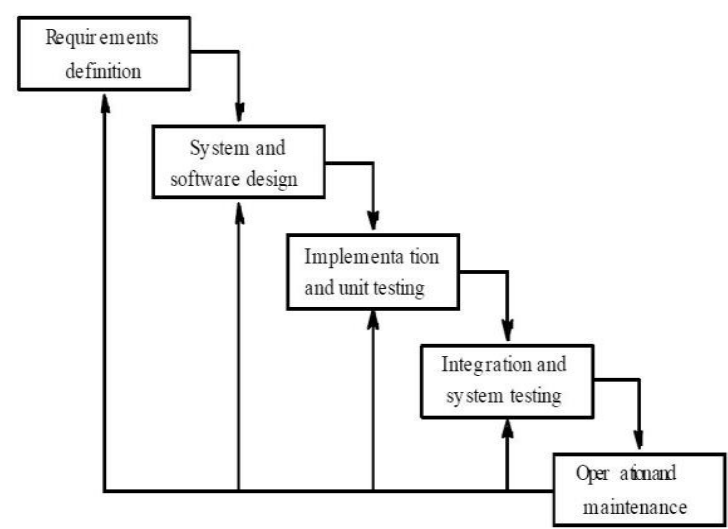

Gambar 3. Metode Pengembangan Perangkat lunak(Abdul Kadir, 2003)

Pada penelitian ini metode yang digunakan adalah metode waterfall. Metode waterfall merupakan metode yang sering digunakan oleh penganalisa sistem. Inti dari metode waterfall adalah pengerjaan dari suatu sistem dilakukan secara berurutan atau secara linear. Jadi jika langkah ke-1 belum dikerjakan, maka langkah 2 tidak dapat dikerjakan. Jika langkah ke-2 belum dikerjakan maka langkah ke-3 juga tidak dapat dikerjakan, begitu seterusnya. Secara otomatis langkah ke-3 akan bisa dilakukan jika langkah ke-1 dan ke-2 sudah dilakukan ( Abdul Kadir, 2003).

\section{Analisa kebutuhan (Requirements )}

Dalam pengembangan sistem ini kebutuhan alat yang akan digunakan nantinya adalah sebagai berikut :

a. Mikrokontroler yang digunakan Atmega328 Arduino Uno. Rangkaian pada mikrokontroler ini berfungsi sebagai pusat kendali dari keseluruhan sistem yang dirancang, IC yang digunakan adalah Atmega 328 yang 
merupakan komponen utama dari rangkaia tersebut seperti gambar 2.2.
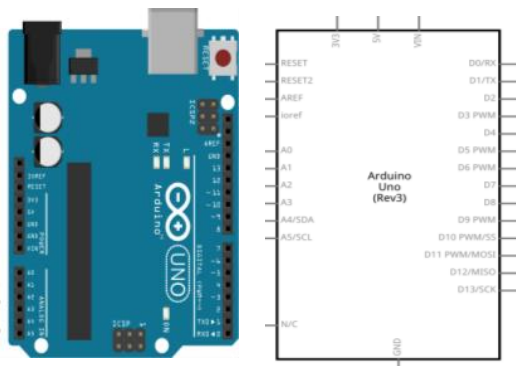

Gambar 4. Mikrokontroler Arduino Uno Atmega328

b. Sensor Ultrasonik HC-SR04 yang digunakan untuk menghitung ketinggian permukaan sampah.

\begin{tabular}{|c|c|}
\hline $\begin{array}{c}\text { Sensor Ultrasonik HC- } \\
\text { SR04 }\end{array}$ & Mikrokontroler \\
\hline Vcc & Vcc (5v) \\
\hline Gnd & Gnd \\
\hline Echo & Pin 11 \\
\hline Trig & Pin 12 \\
\hline
\end{tabular}

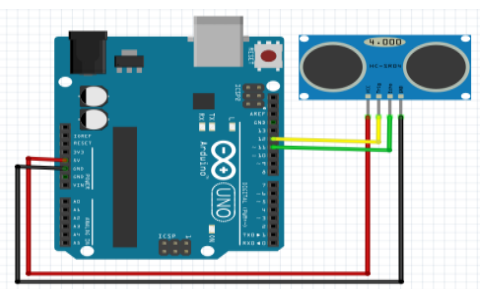

Gambar 5. Rangkaian Sensor HC-SR04 ke Mikrokontroler

c. Modul ESP8266 sebagai media pengirim informasi menggunakan internet (gambar 2.4).

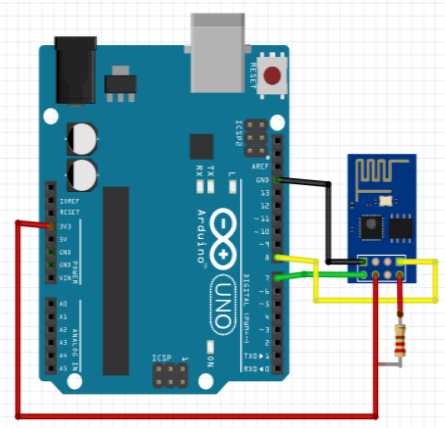

Gambar 6. Rangkaian ESP8266 Mikrokontroler d. Komputer/ Laptop digunakan sebagai media untuk melakukan proses pemograman pada alat.

2. Desain sistem (Desain)

Untuk menghasilkan sistem yang akan dibangun perlu dibuat sebuat perancangan dan desain sistem. Permodelan yang digunakan dalam perancangan sistem adalah object oriented yang meliputi Use Case Diagram dan Activity Diagram untuk menggambarkan arus dari sistem. Sedangkan desain sistem untuk menampilkan serta menghasilkan informasi prngukuran ketinggian sampah dengan rincian (desain output, desain input, desain file dan database).

3. Penulisan kode program (implementation) Penulisan program dengan menggunakan bahasa PHP Hypertext Preprocesor (PHP) sebagai aplikasi yang akan digunakan untuk memproses data dan informasi dari hasil analisis dan perancangan. MySql digunakan sebagai database untuk menyimpan data. Serta sistem yang teritegrasi dengan googlemap untuk menunjukkan lokasi pada peta.

4. Pengujian program ( verification)

Pengujian terhadap sistem yang telah selesai dibangun di perlukan unuk mengetahui apakah masih terdapat kesalahan dalam rangcangan logika atau program apabila masih terdapat kesalahan akan dilakukan perbaikan-perbaikan sehingga program yang telan dibangun siap dan layak untuk digunakan.

5. Penerapan dan maintenance.

Pada tahap ini program yang telah selesai dibangun sesuai dengan perancangan sistem, akan diterapkan pada instansi yang membutuhkan. Tahapan ini sudah menghasilkan suatu sistem yang dapat berjalan secara optimal.

\section{HASIL DAN PEMBAHASAN}

\subsection{Analisa Sistem}

Analisa sistem adalah suatu rangkaian kegiatan untuk menganalisa sistem yang sudah berjalan, lalu bagaimana kita bisa mengembangkan sistem yang sudah mejadi yang lebih baik lagi. Kemudian mendokumentasikan segala kebutuhan yang 
akan dipenuhi dalam membangun sistem yang baru.

\subsection{Perancangan Sistem}

Perancangan sistem ini dibuat dengan pemodelan SDLC (System Development Life Cycle). Pemodelan yang digunakan berupa pemodelan object oriented yang meliputi Use Case Diagram dan Activity Diagram untuk menggambarkan arus dari sistem.

\section{a. Usecase Diagram}

Tujuan dari perancangan use case diagram adalah untuk menjelaskan hal-hal apa saja yang bisa dilakukan oleh actor terhadap sistem yang dirancang. Berikut gambaran use case diagram dari sistem yang dirancang

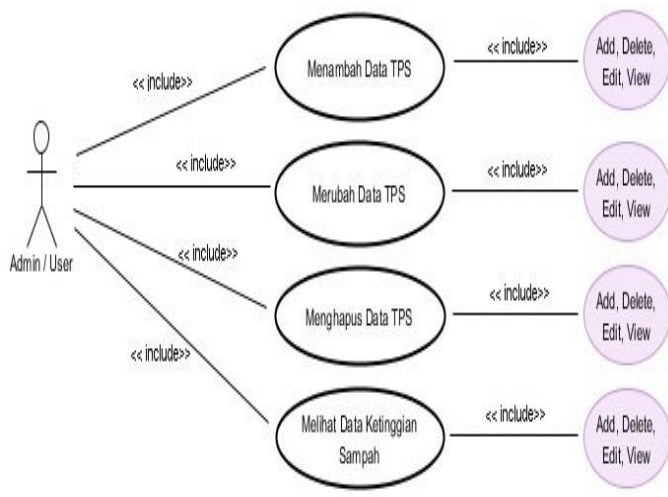

Gambar 7. Use Case Diagram sistem pengukur

ketinggian permukaan sampah pada TPS

\section{b. Activity Diagram}

Activity diagram menggambarkan berbagai aktivitas yang terjadi di dalam sistem yang sedang dirancang dari proses awal sebuah sistem berjalan sampai dengan proses akhir sistem berjalan seperti berikut.

1. Activity Diagram Halaman tambah data TPS (gambar 4.2)

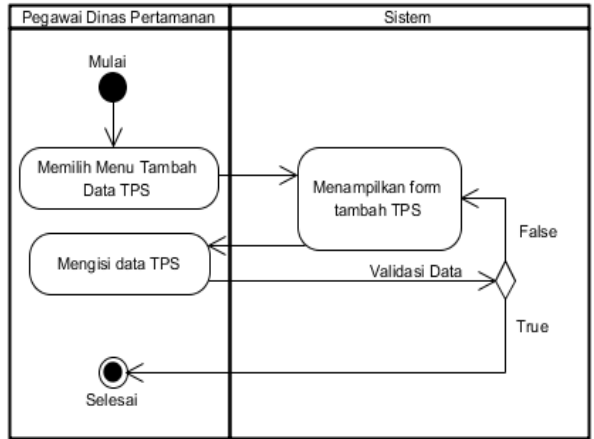

Gambar 8. Activity Diagram Halaman tambah data TPS

2. Activity Diagram Halaman merubah data TPS (gambar 4.3).

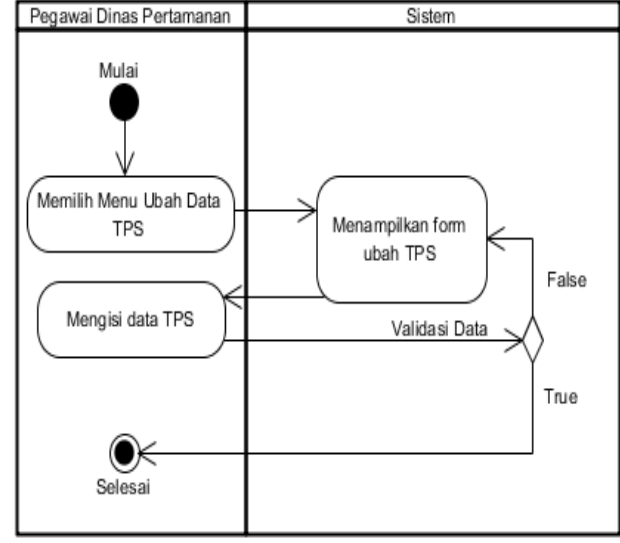

Gambar 9. Activity Diagram Halaman ubah data TPS

3. Activity Diagram Halaman menghapus data TPS (gambar 4.4).

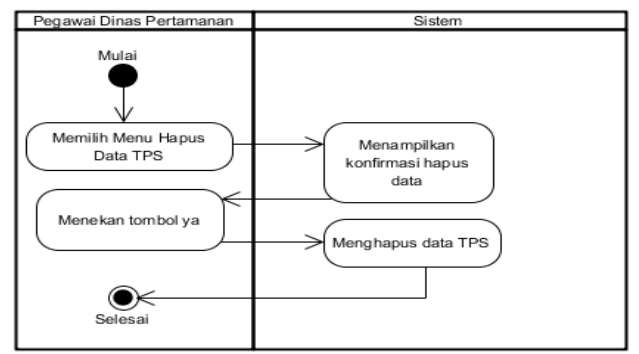

Gambar 10. Activity Diagram hapus data TPS

\subsection{Rancangan Database}

Perancangan database merupakan gambaran umum mengenai table-tabel yang akan digunakan dalam sistem. Perancangan database digunakan sebagai media penyimpanan data serta relasi antara tabeltabel lain yang saling berkaitan.

Adapun rancangan basis data dengan menggunakan nama database db_sampah dan tabel-tabel sebagai berikut:

Tabel 1. Tabel data_result

\begin{tabular}{|l|l|l|l|}
\hline No & Nama & Type & Keterangan \\
\hline 1 & id_result & int(100) & primary key \\
\hline 2 & id_lokasi & int(100) & $\begin{array}{l}\text { Foreign key } \\
\text { references } \\
\text { data_location } \\
\text { (id_lokasi) }\end{array}$ \\
\hline 3 & tinggi & varchar(100) & - \\
\hline 4 & date & date & - \\
\hline
\end{tabular}




\begin{tabular}{|l|l|l|l|}
\hline 5 & time & time & - \\
\hline
\end{tabular}

Tabel 2. Tabel data_location

\begin{tabular}{|l|l|l|l|}
\hline No & $\begin{array}{l}\text { Nama } \\
\text { Field }\end{array}$ & Type & Keterangan \\
\hline 1 & id_lokasi & int(100) & primary key \\
\hline 2 & deskripsi & varchar(100) & - \\
\hline 3 & lat & float & - \\
\hline 4 & lon & float & - \\
\hline
\end{tabular}

\subsection{IMPLEMENTASI SISTEM}

Implementasi sistem merupakan penerapan sistem yang telah dibuat baik dari perangkat keras (Hardware) maupun perangkat lunak (Software) dengan melakukan pengujian secara keseluruhan apakah sistem yang dibuat berjalan sesuai yang diinginkan.

\subsubsection{Perangkaian Perangkat Keras}

Sebelumnya membangun perangkat keras (Hardware) dari sistem, pada tahapan ini kita akan merangkai seluruh komponen perangkat keras sesuai rancangan sebelumnya. Adapun alat dan bahan yang diperlukan dalam perangkaian perangkat keras dapat dilihat pada tabel 3.3 berikut ini :

Tabel 3. Kebutuhan Alat dan Bahan

\begin{tabular}{|c|c|c|c|}
\hline $\begin{array}{l}\mathrm{N} \\
\mathrm{O}\end{array}$ & $\begin{array}{l}\text { ALAT / } \\
\text { BAHAN }\end{array}$ & KEGUNAAN & $\begin{array}{c}\text { GAMBA } \\
\text { R }\end{array}$ \\
\hline 1 & Solder litrik & $\begin{array}{l}\text { Merangkit } \\
\text { sataupun } \\
\text { membongkar } \\
\text { rangkaian } \\
\text { elektronika }\end{array}$ & \\
\hline 2 & $\begin{array}{l}\text { Timah } \\
\text { solder }\end{array}$ & $\begin{array}{l}\text { Bahan } \\
\text { perekat dari } \\
\text { solder listrik }\end{array}$ & \\
\hline 3 & Obeng & $\begin{array}{l}\text { Sebagai alat } \\
\text { untuk } \\
\text { mengencangk } \\
\text { an atau } \\
\text { mengendorka } \\
\text { n baut }\end{array}$ & \\
\hline 4 & $\begin{array}{l}\text { Arduino } \\
\text { Uno } \\
\text { Atmega328 }\end{array}$ & $\begin{array}{l}\text { Modul Induk } \\
\text { untuk } \\
\text { Pengendalian } \\
\text { Sistem }\end{array}$ & \\
\hline
\end{tabular}

\begin{tabular}{|c|l|l|l|}
\hline 5 & $\begin{array}{l}\text { Sensor } \\
\text { Ultrasonik } \\
\text { HC-SR04 }\end{array}$ & $\begin{array}{l}\text { Sensor yang } \\
\text { fungsi } \\
\text { utamanya } \\
\text { sebagai } \\
\text { pengukur } \\
\text { jarak }\end{array}$ & Modul wifi \\
\hline 6 & $\begin{array}{l}\text { Modul } \\
\text { ESP8266 }\end{array}$ & $\begin{array}{l}\text { Penghubung } \\
\text { Pin Modul } \\
\text { dengan } \\
\text { Mikrokontrol } \\
\text { er }\end{array}$ & \\
\hline 10 & $\begin{array}{l}\text { Kabel } \\
\text { Jumper }\end{array}$ & $\begin{array}{l}\text { Wadah } \\
\text { percobaan } \\
\text { untuk } \\
\text { pengisian } \\
\text { sampah }\end{array}$ & \\
\hline 11 & $\begin{array}{l}\text { Keranjang } \\
\text { Sampah }\end{array}$ \\
\hline
\end{tabular}

Berikut ini merupakan gambar dari prototype yang sudah di rangkai (gambar 4.5).

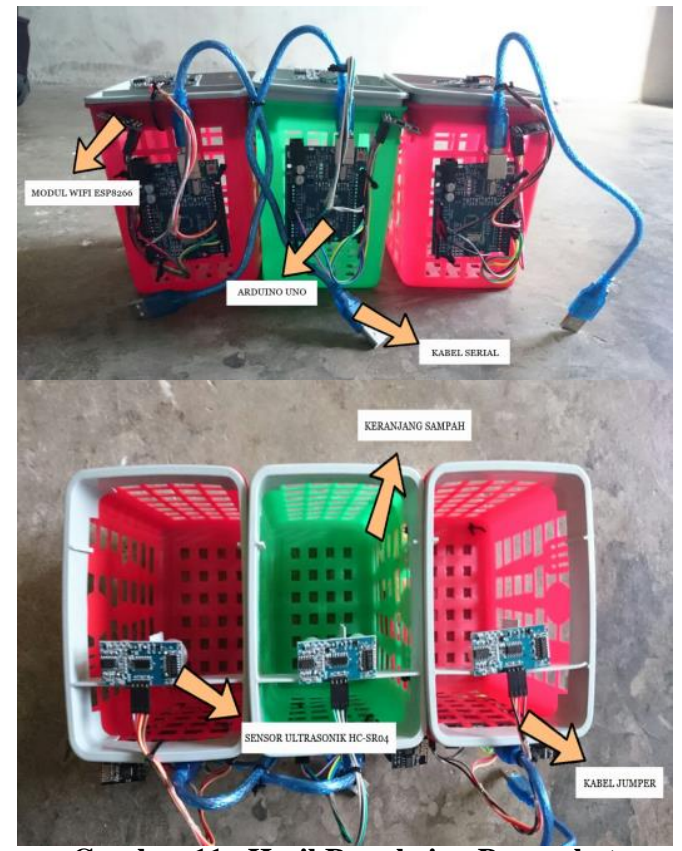

Gambar 11. Hasil Rangkaian Perangkat

Gambar diatas adalah rangkaian komponen alat prototipe yang dibangun yang akan dihubungkan dengan koneksi internet, laptop atau komputer.

\subsubsection{Aplikasi Arduino}

Aplikasi Arduino diperlukan sebagai media pemrograman sekaligus sebagai media pengisian program ke alat. Sebelum menggunakan aplikasi arduino kita perlu melakukan beberapa langkah pengaturan, seperti mengatur jenis board dan port USB yang akan digunakan. Pengaturannya terdapat 
di tab Tools. Dapat dilihat pada gambar berikut ini (gambar 4.6) :

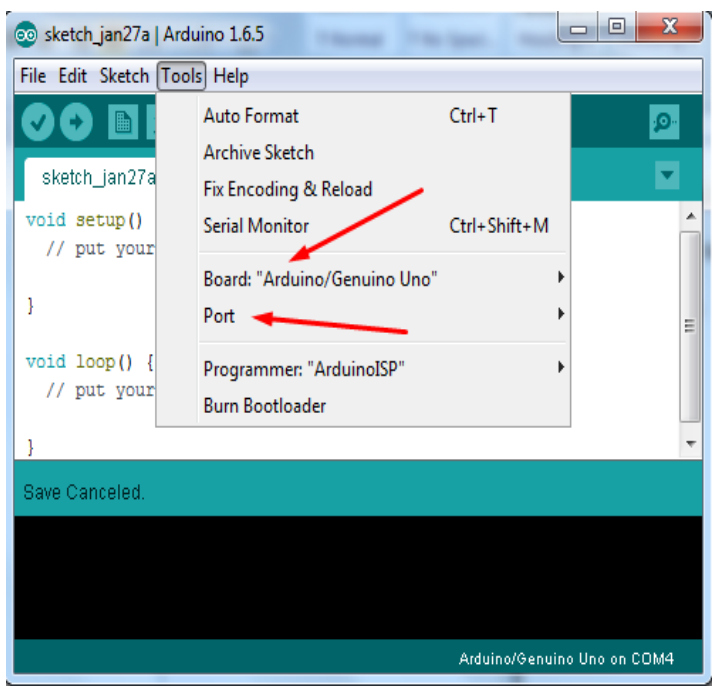

Gambar 12. Pemilihan Board dan Port USB

Setelah dilakukan pengaturan pemilihan Board dan port USB, aplikasi arduino siap dijalankan (gambar 4.7).

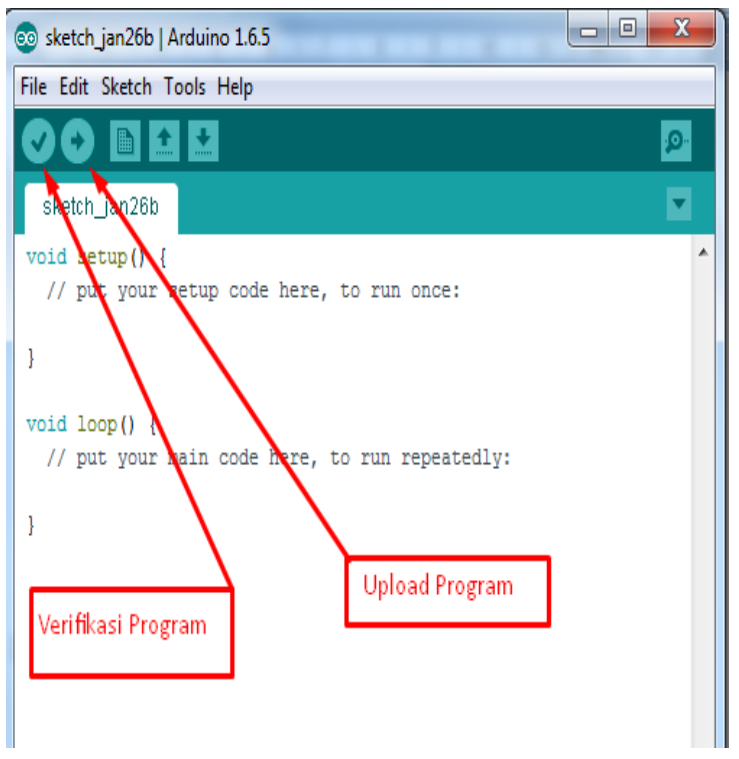

Gambar 13. Verifikasi dan Upload Program

\subsubsection{Aplikasi Web GIS}

Hasil akhir aplikasi Menggunakan Arduino dan WEB GIS yang telah dibangun untuk mengukur ketinggian tumpukan sampah dapat kita lihat seperti gambar dibawah ini:

1. Halaman beranda

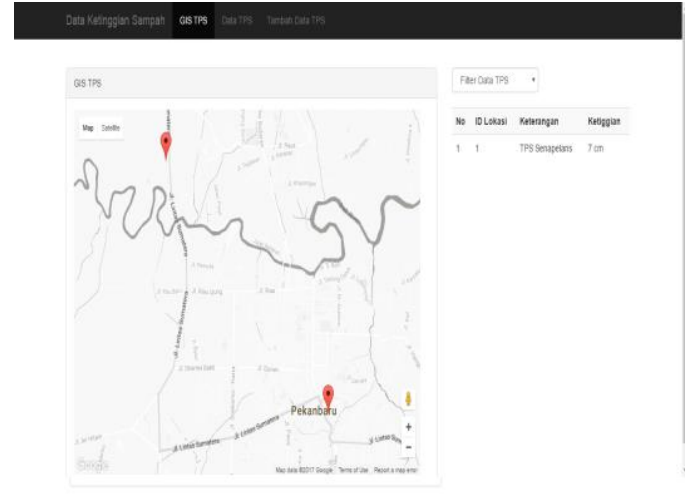

Gambar 14. Halaman beranda

Gambar di atas menggambarkan tampilan implementasi halaman beranda. Dimana kita bisa melihat beberapa tampilan menu, map dan filter data untuk memilih ketinggian sampah berdasarkan letak atau posisi.

\section{SIMPULAN}

Setelah di lakukan pengujian terhadap sistem yang dibangun maka penulis dapat mengambil kesimpulan bawah Secara keseluruhan sistem dan alat yang dibangun berkerja sesuai yang diharapkan. Pengembangan dari penelitian sebelumnya dengan menggunakan sinyal radio diubah dengan menggunakan koneksi internet berjalan dengan baik. Apabila diterapkan pada dinas Pertamanan Kota Pekanbaru tentu saja akan sangat membantu untuk menyelesaikan persoalan penanganan sampah.

Agar penelitian ini lebih sempurna lagi, penulis menyarankan untuk dikembangkan lagi dengan menggunakan sensor yang lebih canggih, yang dapat mendeteksi sampah yang berserakkan dan tidak terpokus pada tempat pembuangan sampah sementara.

\section{UCAPAN TERIMAKASIH}

Ucapan terimakasih kepada STMIK Amik Riau, Dinas Tata Kota Pekanbaru dan semua pihak yang telah membantu atas bantuan melakukan penelitian ini.

\section{DAFTAR PUSTAKA}

Abdul Kadir, 2003, Pengenalan Sistem Informasi, Andi Offset, Yogyakarta. 
Ari, B.S \& Martinus \& Sugiyanto, 2013, 'Pembuatan Otomasi Pengaturan Kereta Api, Pengereman dan Palang Pintu Pada Rel Kereta Api Mainan Berbasis Mikrokontroler ', vol. 1, No. 1.

Dedi Setiawan \& dkk, 2013, 'Rancang Bangun Alat Pembuka dan Penutup Tong Sampah Otomatis Berbasis Mikrokontroler'.

Eddy Prahasta, 2009, Sistem Informasi Geografis, Informatika Bandung, Bandung.

Rosa, A.S \& M Shalahuddin, 2011, Rekayasa Perangkat Lunak, Modula,Bandung.

Sinantya, F.A \& Hendi, H.R, 2015, 'Implementasi Sistem Bel Rumah Otomatis Berbasis Sensor Ultrasonik', vol. 1, No. 3.

Syaifudin Ramadhani, 2013, 'Rancang Bangun Sistem Informasi Geografis Layanan Kesehatan Di Kecamatan Lamongan Dengan PHP MySQL', vol. 5, No. 2.

Tata Sutabri, 2012, Konsep Sistem Informasi, Andi Offset, Yogyakarta. 